\title{
Comparative Study of Microbial Activities and Biodegradation-Abilities of Undefined Consortium in Some Hydrocarbon Contaminated Sites in the Niger Delta, Nigeria
}

\author{
0. O. Olanipekun ${ }^{1}$, A. O. Ogunbayo ${ }^{1}$, S. C. U. Nwachukwu' ${ }^{2}$, R. A. Bello ${ }^{1}$ \\ ${ }^{1}$ Department of Chemical Engineering, University of Lagos, Yaba, Lagos \\ ${ }^{2}$ Department of Microbiology, University of Lagos, Yaba, Lagos \\ Email: *oolanipekun@unilag.edu.ng
}

Received 27 January 2015; accepted 13 February 2015; published 25 February 2015

Copyright (C) 2015 by authors and Scientific Research Publishing Inc.

This work is licensed under the Creative Commons Attribution International License (CC BY).

http://creativecommons.org/licenses/by/4.0/

\section{(c) (i) Open Access}

\begin{abstract}
The microbial activities and the biodegradation-abilities of undefined consortium in contaminated soils in the Niger Delta of Nigeria were studied. The Respirametry technique was adopted to evaluate the microbial activities while the soils were incubated with $2 \%(v / v)$ crude oil in mineral salt medium at $37^{\circ} \mathrm{C}$ in three stages of two weeks each in a shake flask. At the end of the last phase, components of the crude oil degraded by the undefined consortium in the soils were identified with the gas chromatographic techniques. The consortia of the different samples studied showed different degree of capacities on the crude oil, removing a large number of components of the crude oil, making the areas potentially suitable for in-situ bioremediation.
\end{abstract}

Keywords

Microbial Activities, Undefined Consortium, Crude Oil, In-Situ, Bioremediation

\section{Introduction}

Niger Delta remains the richest part of Nigeria in terms of natural resources which include large deposits of oil

"Corresponding author.

How to cite this paper: Olanipekun, O.O., et al. (2015) Comparative Study of Microbial Activities and Biodegradation-Abilities of Undefined Consortium in Some Hydrocarbon Contaminated Sites in the Niger Delta, Nigeria. Journal of Environmental Protection, 6, 138-145. http://dx.doi.org/10.4236/jep.2015.62016 
and gas, making it the home of the petroleum industry with distribution of onshore and offshore oil fields. This has exposed the region to large or repeated oil spills or leaks frequently exhibiting long term environmental problems [1]. Due to the adverse effects of oil (hydrocarbon) contaminants on their environments, the future of the region is being threatened. Thus, there is the need to focus research on how to best remediate the contaminated sites (soils or water).

Bioremediation, which has been established as an efficient, cost-effective and environmentally friendly process, in contrast to the chemical and physical processes of remediating organic compounds contaminated environments, is a system that exploits the ability of some microorganisms to degrade the contaminants. The process depends utmost on the microbial community structure, and thrives on the ability to enrich and maintain microbial populations and activities within the target environment.

The number of microorganisms in a given environment can serve as an indicator of how well the environment can support microbial growth and indirectly, it's potential for biodegradation [2]. The biotransformation hinges on the significance of biodegradative contribution of the indigenous microorganisms [3]-[5]. Thus, in situ bioremediation is a site-specific process, and feasibility studies are required before full-scale remediation can be applied [6]. There is evidence that biodegradation of hydrocarbons in petroleum derivatives is not due to the ability of a single strain of microorganism but by combination of abilities of a mixture of strains of different microorganisms [7]. The biodegradation of a mixture of hydrocarbons as present in crude oil requires the enzymic systems which may be supplied by a culture of mixed or heterogeneous population of microorganisms. This allows for complimenting the role of the catalytic capacities of the different strains to degrade or transform a mixture of hydrocarbons (synergism) [8] [9].

Various studies have examined the ability of consortia of hydrocarbon degrading microbes to degrade different petroleum products and the results have been encouraging. For instance, Malik and Ahmed [7] studied the degradation of petroleum hydrocarbons by oil field isolated bacterial consortium, and found out that consortium gave a better ability of degrading long chain n-alkanes and crude oil at high concentration. Also, few have study the ability of consortium of contaminated sites.

Soil, especially contaminated one is a natural platform to obtain mixed culture of population of hydrocarbon degrading microorganisms. Biodegradative capacity of undefined contaminated sites is germane in selecting bioremediation process (either in-situ or ex-situ) in a given site. It gives firsthand information on the potentials of the indigenous hydrocarbon utilizers to remediate the environment. Also, evaluation of specific metabolic activities, such as $\mathrm{CO}_{2}$ production or oxygen consumption, provides information on the biodegradability potential of hydrocarbons in soils, and an increase of the rate of respiration after oil application is an indication of successful hydrocarbon mineralization.

Therefore, this present study aims principally to elucidate and compare the abilities of undefined consortium of some sites in the Niger Delta of Nigeria, and to study the microbial activities in these sites.

\section{Materials and Methods}

The methods used by Margesin et al. [5], Uzoamaka et al. [10] and Obire and Anyanwu [1] were integrated and adopted in this work. This involved using soil samples, both contaminated with crude oil and pristine (uncontaminated), serving as control. The samples were collected from surface soils (0 - $15 \mathrm{~cm}$ depth) from two and three communities (as sites) in Delta and River states respectively. The soil samples collections were made from 3 - 4 random points per sample sites and mixed to form a composite soil sample with a sterile scoop and transferred aseptically into sterile polyethene bags. All soil samples for future analysis were stored in accordance to ISO and OECD standards at $4^{\circ} \mathrm{C} \pm 2^{\circ} \mathrm{C}$.

\subsection{Microbial Activities Analysis}

Respirametry technique was adopted, since it allows an in depth analysis of the microbial population dynamics. Margesin et al. [5] and Eze and Eze [11] procedures were adopted. The soil respiration was measured from incubation of $100 \mathrm{~g}$ soil samples kept in hermetically sealed $250 \mathrm{ml}$ glass flask for 21 days at room temperature. To achieve this, $100 \mathrm{ml}$ conical flask containing $50 \mathrm{ml}$ of $0.50 \mathrm{mold} \cdot \mathrm{m}^{-1}$ of $\mathrm{NaOH}$ solution was used to capture the $\mathrm{CO}_{2}$ produced from the respiration.

The conductance of the $\mathrm{NaOH}$ solution was measured using Jensy Model 712 Conductance Instrument after 
each incubation time $(1,3,5,7,13,17$ and 21 days). The microbial activity was monitored in triplicate for the released of $\mathrm{CO}_{2}$ [12]. The produced $\mathrm{CO}_{2}$ was calculated from the following equation.

$$
m=22 \frac{\lambda_{1}-\lambda_{x}}{\lambda_{1}-\lambda_{2}} V C
$$

where $\lambda_{x}$ is the conductivity value of the sample, $\lambda_{2}$ is the conductivity value of $\mathrm{Na}_{2} \mathrm{CO}_{3}, \lambda_{1}$ is the conductivity value of $\mathrm{NaOH}, V$ is the volume of the standard $\mathrm{NaOH}$ solution, $C$ is its concentration in mol. $\mathrm{dm}^{-3}$ and $m$ is the estimated mass of absorbed $\mathrm{CO}_{2}$ in $\mathrm{mg}$.

\subsection{Testing of Crude Oil Utilization-Ability of the Environmental Consortium}

The abilities of the undefined consortium in the sampled soils were confirmed by inoculating $10 \mathrm{~g}$ of each sample in separate cotton plugged $250 \mathrm{ml}$ Erlenmeyer flasks containing sterile liquid minimal salt medium (whose composition was same as used in the estimation of hydrocarbon utilizing bacteria and fungi previously). The liquid medium and crude oil were tyndalised separately at $100^{\circ} \mathrm{C}$ at atmospheric pressure for $30 \mathrm{~min}$, while the sterile crude oil which served as source of carbon and energy was added at $1 \%-2 \%(v / v)$ to make up a final volume of $90 \mathrm{ml}$ sterile liquid minimal salt medium and this was the first enrichment. Control flask containing the liquid medium and the $1 \%$ - $2 \%$ crude oil but without soil sample was also prepared. The flasks were monitored and agitated in water bath shaker for a period of 14 days. For the second enrichment phase, $10 \mathrm{ml}$ of aliquot of each soil sample was transferred to fresh $90 \mathrm{ml}$ medium containing $1 \%-2 \%(v / v)$ crude oil and also monitored for 14 days in water bath shaker.

The same procedure was repeated for the third enrichment phase, in order to re-confirm the biodegradation abilities of the microorganisms. At the end of each stage, microbial loads were determined by plating aliquots $(0.1 \mathrm{ml})$ from $10^{-3}$ and $10^{-4}$ dilutions of samples on potato dextrose agar (PDA) plates and $10^{-5}, 10^{-7}$ and $10^{-8}$ dilutions on nutrient agar (NA) plates for the fungi and bacteria respectively. Hydrocarbon utilizing isolates were isolated from the last phase of enrichment, while the residual hydrocarbons present in the media after the last phase of enrichment were determined by Gas Chromatograph/mass spectrometer GC/MS analysis [13] [14].

\section{Result and Discussion}

\subsection{Soil Microbial Activities Study}

The respirometry technique has allowed an in-depth analysis of the microbial population dynamics, by comparing the activities of indigenous microbial population in both pristine (uncontaminated) and contaminated soils. The relationship between accumulated carbon (IV) oxide production and time of incubation are shown in Figures 1-5. The cumulative values obtained reflect the distinct behavior for the contaminated and uncontaminated soil samples as a result of microbial degradative activities.

The results as shown in Figure 2 and Figure 6 (representing sites Uwvie, in Delta State and Pete, Rivers State respectively) indicated that the potential activities of the indigenous microbes were higher than that of the actual. That is there are strong positive responses from the indigenous microbial population, indicating their biodegradative contributions. This suggests that the microbial activities are not so impacted and interfered with by the crude oil hydrocarbons. Furthermore, this may imply that the biodegradability potential of hydrocarbons in soils of these sites may be high, that the soil can be successfully remediated by natural attenuation. In other word, not only are viable hydrocarbons utilizing microbes present but they are efficient in mineralizing the hydrocarbons.

The results obtained as shown in Figures 3-5 (representing sites Ethiope (Delta State), Eleme and Gokana, (Rivers State) respectively) showed that the activities of microbes in uncontaminated soils (actual) are higher than that of the contaminated (potential). That is, there are depressed microbial activities as a result of the contamination. Similar observation was reported by Margesin et al. [5]. These results depict two things which are 1) that there is a decrease in the heterotrophs in the contaminated soils, and 2) an indication of the abilities of the indigenous microorganisms to degrade or utilize the hydrocarbons effectively. In these contaminated sites, from the results obtained, it is implied that there exists a population of hydrocarbon utilizers whose activities are not enough to mineralize the hydrocarbons present. In such situation, bioremediation would require enhancement either by biostimulation or bioaugmentation. 

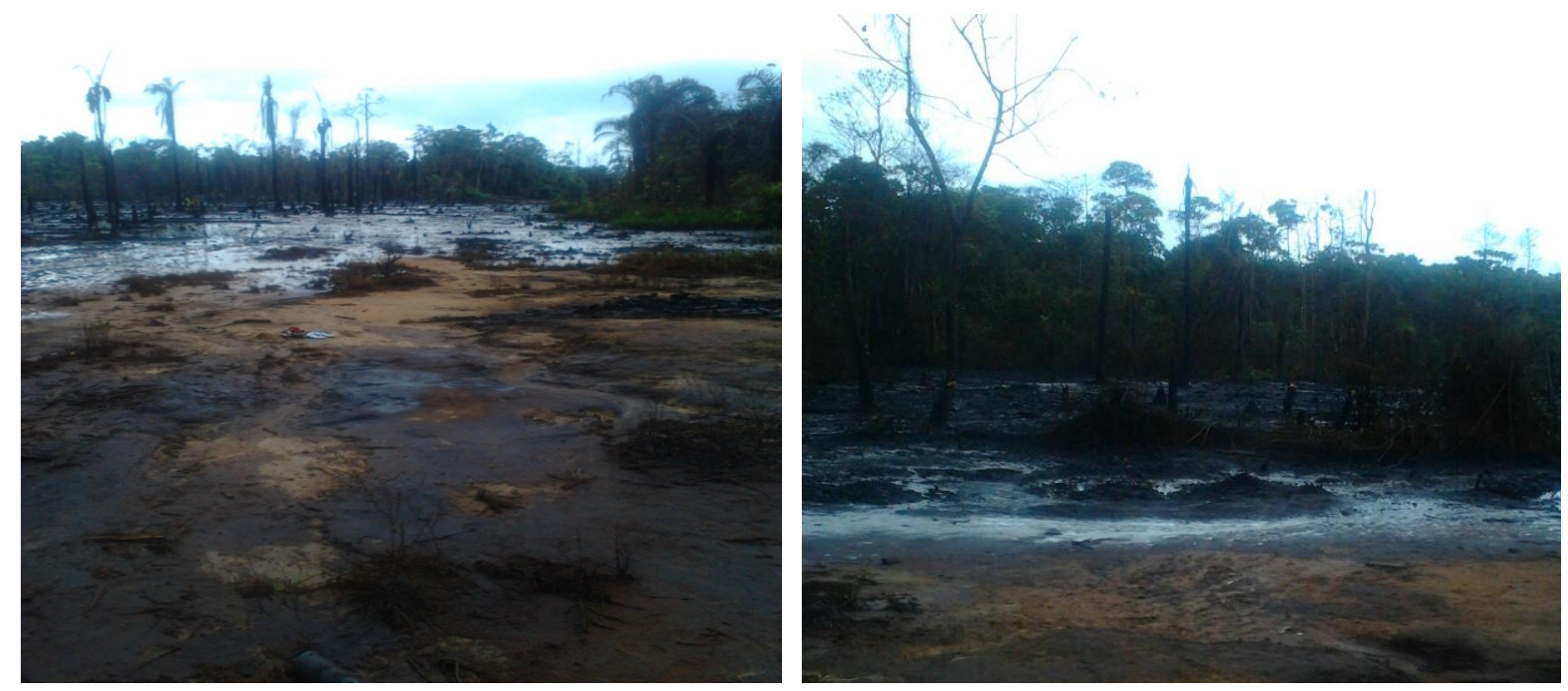

Figure 1. Picture of contaminated site at Jesse, Ethiope L.G.A, Delta State.

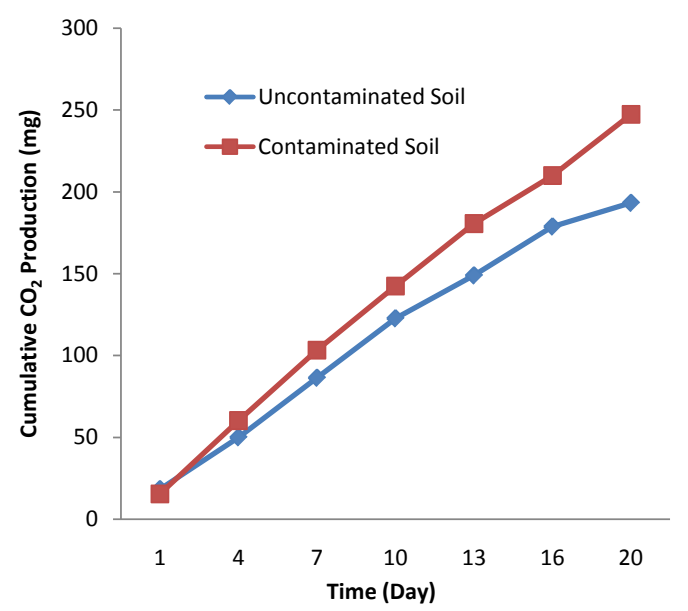

Figure 2. Accumulated $\mathrm{CO}_{2}$ production during 21 days incubation of soil samples from Effuru, Delta State.

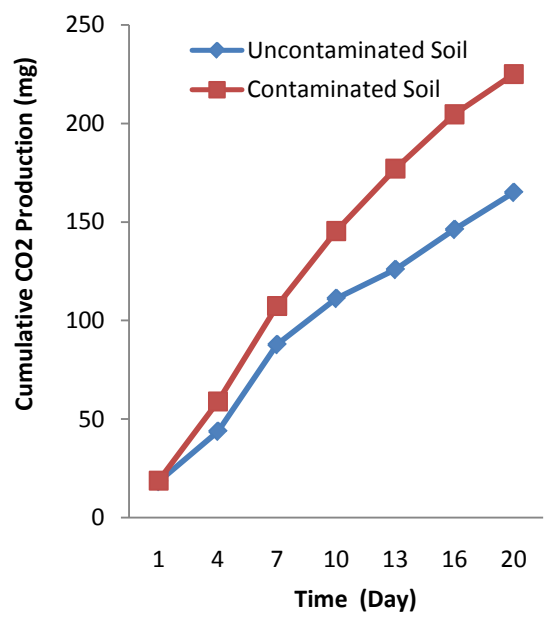

Figure 3. Accumulated $\mathrm{CO}_{2}$ production during 21 days incubation of soil samples from Ethiope, Delta State. 


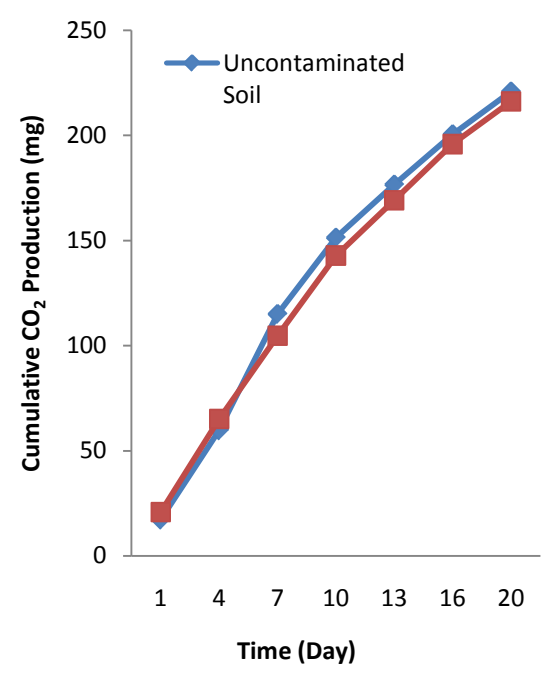

Figure 4. Accumulated $\mathrm{CO}_{2}$ production during 21 days incubation of soil samples from Eleme, River State.

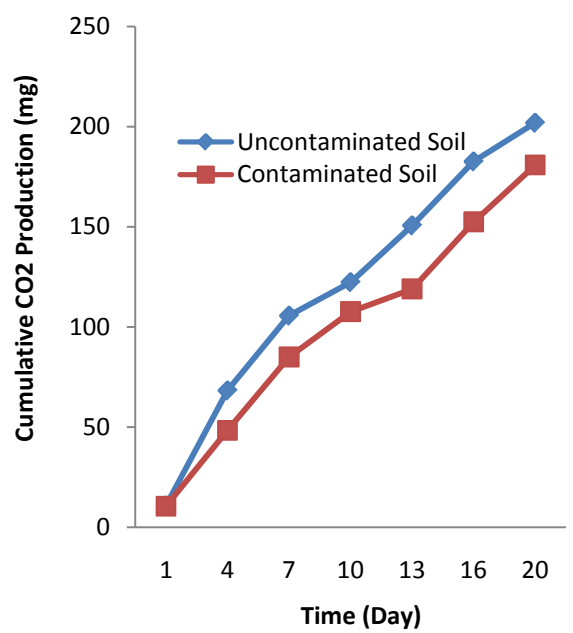

Figure 5. Accumulated $\mathrm{CO}_{2}$ production during 21 days incubation of soil samples from Gokana, River State.

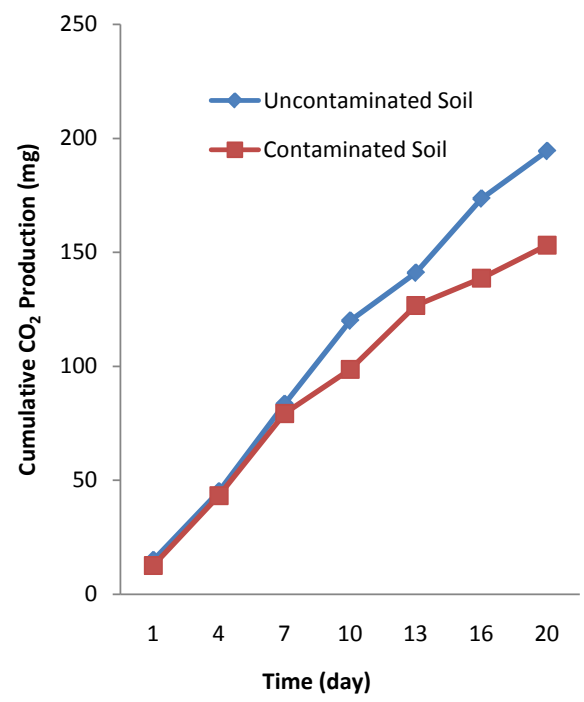

Figure 6. Accumulated $\mathrm{CO}_{2}$ production during 21 days incubation of soil samples from Tai, River State. 


\subsection{Biodegradability in the Undefined Environments (Soils)}

The biodegradability of the total petroleum hydrocarbon (TPH) of Nigerian crude oil within the non-defined consortium of microbial population in the Niger Delta soils were qualitatively evaluated after the last phase of two-week enrichment technique using the Gas Chromatographic, GC. Table 2 shows the microbial population loads of the soil samples while the Table 1 shows the interpretation of chromatograms of the residuum hydrocarbons after the enrichment period.

It was observed that the biodegradation or utilization of the hydrocarbons in the crude oil by the non-defined consortium resulted in the growth of the microbial population, as there were increases in the microbial load of both bacteria and fungi during the period of enrichment as shown in Table 2.

The results showed that all the soil samples harbored adequate population (consortium) of hydrocarbon degraders whose affectivity biodegraded the hydrocarbons in the crude oil. These have resulted in the disappearance of majority of the component of petroleum hydrocarbons. It is a strong implication that the indigenous consortium in the Niger Delta of Nigeria, though non-defined, could effectively biodegrade crude oil. This corroborated with the result of Margesin et al. [5] which reported the degradation ability of indigenous microorganisms on component of petroleum hydrocarbons. Consequently, there is need to encourage the use of bioremediation programmes in the region to eliminate hydrocarbon pollutants.

The analysis of crude oil hydrocarbons by GC-MS is a powerful measure to evaluate the biodegradation process and can play an important role validating the $\mathrm{CO}_{2}$ evolution data as a tool for evaluating hydrocarbon degradability.

In comparing the chromatographic properties of the sample locations, control flask and the crude oil as shown

Table 1. Interpretation of the gas chromatograph analysis showing residual hydrocarbons.

\begin{tabular}{|c|c|c|c|c|c|c|c|c|c|c|c|}
\hline CRUDE OIL & CONTROL & DUEA & DUEB & DEJA & DEJB & REEA & REEB & RGKA & RGKB & RTPA & RTPB \\
\hline \multicolumn{12}{|l|}{ 2-Methyl trans-decalin } \\
\hline 2-Methyl naphthalene & $\mathrm{xxx}$ & & & & $\mathrm{xxx}$ & & & & & & \\
\hline \multicolumn{12}{|l|}{ 2, 6, 10-Trimethyl dodecane } \\
\hline \multicolumn{12}{|l|}{ n-Tetracosanol-1 } \\
\hline 2, 7-Dimethyl naphthalene & $\mathrm{xxx}$ & & & & $\mathrm{xxx}$ & & & & & & \\
\hline 1, 7-Dimethyl naphthalene & $\mathrm{xxx}$ & & & & & & & & & & \\
\hline 2, 3, 6-Trimethyl naphthalene & $\mathrm{xxx}$ & & & & & $\mathrm{xxx}$ & $\mathrm{xxx}$ & & $\mathrm{xxx}$ & & \\
\hline \multicolumn{12}{|l|}{ Tridecane } \\
\hline \multicolumn{12}{|l|}{ Heptadecane } \\
\hline 2, 6-Dimethyl heptadecane & $\mathrm{xxx}$ & $\mathrm{xxx}$ & $\mathrm{xxx}$ & $\mathrm{xxx}$ & $\mathrm{xxx}$ & $\mathrm{xxx}$ & $\mathrm{xxx}$ & & $\mathrm{xxx}$ & $\mathrm{xxx}$ & $\mathrm{xxx}$ \\
\hline Hexadecane & $\mathrm{xxx}$ & $\mathrm{xxx}$ & $\mathrm{xxx}$ & & $\mathrm{xxx}$ & $\mathrm{xxx}$ & $\mathrm{xxx}$ & & & & \\
\hline 2, 6, 11-Trimethyl dodecane & $\mathrm{xxx}$ & $\mathrm{xxx}$ & $\mathrm{xxx}$ & $\mathrm{xxx}$ & $\mathrm{xxx}$ & & & $\mathrm{xxx}$ & & $\mathrm{xxx}$ & \\
\hline \multicolumn{12}{|l|}{ Nonadecane } \\
\hline \multicolumn{12}{|l|}{ Heptacosane } \\
\hline \multicolumn{12}{|l|}{ Heneicosane } \\
\hline Dodecane & & & & & & & $\mathrm{xx}$ & & & & \\
\hline \multicolumn{12}{|l|}{ Tricosane } \\
\hline \multicolumn{12}{|l|}{ Octadecane } \\
\hline \multicolumn{12}{|l|}{ 5-Butyl docosane } \\
\hline \multicolumn{12}{|l|}{ Hexacosane } \\
\hline Octacosane & & & & & & & & & & & \\
\hline
\end{tabular}

Key: xxx—indicates presence, A—uncontaminated soil, B—contaminated soil, DUE, DEJ, REE, RGK and RTP (see Table 3). 
Table 2. Indigenous microbial populations in enrichment medium.

\begin{tabular}{|c|c|c|c|c|c|}
\hline Site location & Site description & Microbial type & Phase I (cfu/g) & Phase II (cfu/g) & Phase III (cfu/g) \\
\hline \multirow{4}{*}{ DUE } & \multirow{2}{*}{ A } & Bacteria & $3.25 \times 10^{7}$ & $1.03 \times 10^{9}$ & $2.50 \times 10^{10}$ \\
\hline & & Fungi & $7.50 \times 10^{5}$ & $0.88 \times 10^{6}$ & $3.50 \times 10^{6}$ \\
\hline & \multirow{2}{*}{ B } & Bacteria & $2.00 \times 10^{6}$ & $1.00 \times 10^{9}$ & $2.00 \times 10^{10}$ \\
\hline & & Fungi & $1.25 \times 10^{5}$ & $1.68 \times 10^{6}$ & $2.25 \times 10^{6}$ \\
\hline \multirow{4}{*}{ DEJ } & \multirow{2}{*}{ A } & Bacteria & $2.53 \times 10^{8}$ & $7.00 \times 10^{9}$ & $3.05 \times 10^{11}$ \\
\hline & & Fungi & $3.70 \times 10^{6}$ & $1.45 \times 10^{6}$ & $6.75 \times 10^{6}$ \\
\hline & \multirow{2}{*}{ B } & Bacteria & $1.28 \times 10^{8}$ & $7.50 \times 10^{9}$ & $1.00 \times 10^{11}$ \\
\hline & & Fungi & $5.20 \times 10^{6}$ & $2.43 \times 10^{6}$ & $8.50 \times 10^{6}$ \\
\hline \multirow{4}{*}{ REE } & \multirow{2}{*}{ A } & Bacteria & $2.00 \times 10^{8}$ & $1.60 \times 10^{9}$ & $1.50 \times 10^{10}$ \\
\hline & & Fungi & ND & $0.43 \times 10^{6}$ & $6.25 \times 10^{6}$ \\
\hline & \multirow{2}{*}{ B } & Bacteria & $7.2 \times 10^{8}$ & $3.18 \times 10^{9}$ & $6.00 \times 10^{10}$ \\
\hline & & Fungi & $7.50 \times 10^{6}$ & $0.93 \times 10^{6}$ & $1.05 \times 10^{7}$ \\
\hline \multirow{4}{*}{ RGK } & \multirow{2}{*}{ A } & Bacteria & $2.35 \times 10^{8}$ & $2.40 \times 10^{9}$ & $5.00 \times 10^{10}$ \\
\hline & & Fungi & $1.35 \times 10^{6}$ & $3.30 \times 10^{6}$ & $5.75 \times 10^{6}$ \\
\hline & \multirow{2}{*}{ B } & Bacteria & $7.18 \times 10^{8}$ & $7.00 \times 10^{9}$ & $2.00 \times 10^{10}$ \\
\hline & & Fungi & $7.40 \times 10^{6}$ & $3.37 \times 10^{6}$ & $5.50 \times 10^{6}$ \\
\hline \multirow{4}{*}{ RTP } & \multirow{2}{*}{ A } & Bacteria & $3.45 \times 10^{8}$ & $8.25 \times 10^{9}$ & $5.00 \times 10^{10}$ \\
\hline & & Fungi & $3.65 \times 10^{6}$ & $2.70 \times 10^{6}$ & $1.25 \times 10^{7}$ \\
\hline & \multirow{2}{*}{ B } & Bacteria & $5.93 \times 10^{8}$ & $1.20 \times 10^{9}$ & $5.50 \times 10^{10}$ \\
\hline & & Fungi & $3.35 \times 10^{6}$ & $2.98 \times 10^{6}$ & $1.75 \times 10^{7}$ \\
\hline
\end{tabular}

Key: A—uncontaminated soil, B—contaminated soil, ND—not determined.

Table 3. Sample sites description.

\begin{tabular}{ccc}
\hline S/No. & Abbreviation & Description: state, local government area, community \\
\hline 1 & DEJ & Delta, Ethiope, Jesse \\
2 & DUE & Delta, Uwie, Effurun \\
3 & RTP & Rivers, Tai, Pete \\
4 & REE & Rivers, Ebubu, Eleme \\
5 & RGK & Rivers, Gokana \\
\hline
\end{tabular}

in Table 1, the absence of some of the hydrocarbons initially present in the crude oil could be related to abiotic factors, and explained their absence in the control flask and the sample locations at the end of enrichment period. The same was also observed in the work of Malik and Ahmed [7] and they contributed to disappearance and decrease of significant quantities of the aliphatic and aromatics hydrocarbons.

Chromatographic characteristics of various soil samples showed removal or disappearance of different hydrocarbons. The degree of disappearance was found to be more in the location RGKA and RTPB, where 2, 6, 11-trimethyl dodecane and 2, 6-dimethyl heptadecane respectively were the only identified hydrocarbon peak in chromatograph (Table 1). The 2, 6-dimethyl heptadecane was identified in every other locations expect in RGKA while 2, 6, 11-trimethyl dodecane was not only found in locations such as REEA, REEB, RGKB and RTPB. This could be explained that consortium of hydrocarbon utilizing microbes present in different locations have different capability. Hence, there is need of bioaugmentation with selected strains to degrade the recalcitrant molecules. 


\section{Conclusion}

The biodegradation ability of the naturally present consortium of microorganisms in the soil samples from some hydrocarbon contaminated sites was studied. Though with slight exceptions, the study has shown that there are depressed microbial activities as a result of the contamination. Generally, the result indicates that the biodegradability potential of hydrocarbons in soils of these sites may be high, that the soil can be successfully remediated by natural attenuation. However, the result also explained that consortium of hydrocarbon utilizing microbes present in different locations has different capability, and that there is the need to embark on in-situ bioremediation involving bioaugmentation and biostimulation processes.

\section{Acknowledgements}

The authors of work this would like to appreciate University of Lagos for the grant received through the Central Research, CRC, for this research.

\section{References}

[1] Obire, O. and Anyanwu, E.C. (2009) Impact of Various Concentration of Crude Oil on Fungal Populations of Soil. International Journal of Environmental Science and Technology, 6, 211-218. http://dx.doi.org/10.1007/BF03327624

[2] Bossert, I.D. and Compeau, G.C. (1995) Cleanup Contamination in Soil.

[3] Margesin, R., Walder, G. and Schminer, F. (2000) The Impact of Hydrocarbon Remediation (Diesel Oil and Polycyclic Aromatic Hydrocarbon) on Enzyme Activities and Microbial Properties of Soil. Acta Biotechnology, 20, 313-333. http://dx.doi.org/10.1002/abio.370200312

[4] Leeson, A. and Hinchee, R.E. (1997) Soil Bioventing, Principles and Practice. CRC, Lewis Publishers, Boca Raton.

[5] Margesin, R., Labbe, D., Schinner, F., Greer, C.W. and Whyte, L.G. (2003) Characterization of Hydrocarbon-Degrading Microbial Populations in Contaminated and Pristine Alpine Soils. Applied and Environmental Microbiology, 69, 3085-3092. http://dx.doi.org/10.1128/AEM.69.6.3085-3092.2003

[6] Balb, M.T., Al-Awadhi, N. and Al-Daher, R. (1998) Bioremediation of Soil-Contaminated Soil: Microbiological Methods for Feasibility Assessment and Field Evacuation. Journal of Microbiological Methods, 32, 155-164. http://dx.doi.org/10.1016/S0167-7012(98)00020-7

[7] Malik, Z.A. and Ahmed, S. (2012) Degradation of Petroleum Hydrocarbons by Oil Field Isolated Bacterial Consortium. African Journal of Biotechnology, 11, 650-658.

[8] Forster, C. and Wase, J. (1989) Environmental Biotechnology. Ellis Horwood Publishers, England, 49-51.

[9] Olanipekun, O.O., Ogunbayo, A.O. and Layokun, S.K. (2012) A Study of the Ability of Pseudomonas Aeruginosa and Pseudomonas fluorescens to Degrade Diesel Oil. JETEAS, 3, 429-434.

[10] Uzoamaka, G.O., Floretta, T. and Florence, M.O. (2009) Hydrocarbon Degradation Potentials of Indigenous Fungal Isolates from Petroleum Contaminated Soils. J. Phy.Nat.Scs., 3, 1-6.

[11] Eze, V.C. and Eze, B.N. (2010) Isolation and Characterization of Microorganisms Involved in the Degradation of Refined Petroleum Products Polluted Sites in Elele, Rivers State Nigeria. International Journal of Current Research, 8, 91-95.

[12] Critter, S.A.M, Freitas, S.S. and Airobi, C. (2004) Comparison of Microbial Activity in Some Brazilian Soils by Microcalorimetre and Respirometric Methods. Thermochimica Acta, 410, 35-46. http://dx.doi.org/10.1016/S0040-6031(03)00371-X

[13] Omotayo, A.E., Ojo, O.Y. and Amund, O.O. (2012) Crude oil Degradation by Microorganisms in Soil Composts. Research Journal of Microbiology, 7, 209-218. http://dx.doi.org/10.3923/jm.2012.209.218

[14] Malatova, K. (2005) Isolation and Characterization of Hydrocarbon Degrading Bacteria from Environmental Habitats in Western New York State. A Thesis of Master of Science, Department of Chemistry, Rochester. 
Scientific Research Publishing (SCIRP) is one of the largest Open Access journal publishers. It is currently publishing more than 200 open access, online, peer-reviewed journals covering a wide range of academic disciplines. SCIRP serves the worldwide academic communities and contributes to the progress and application of science with its publication.

Other selected journals from SCIRP are listed as below. Submit your manuscript to us via either submit@scirp.org or Online Submission Portal.
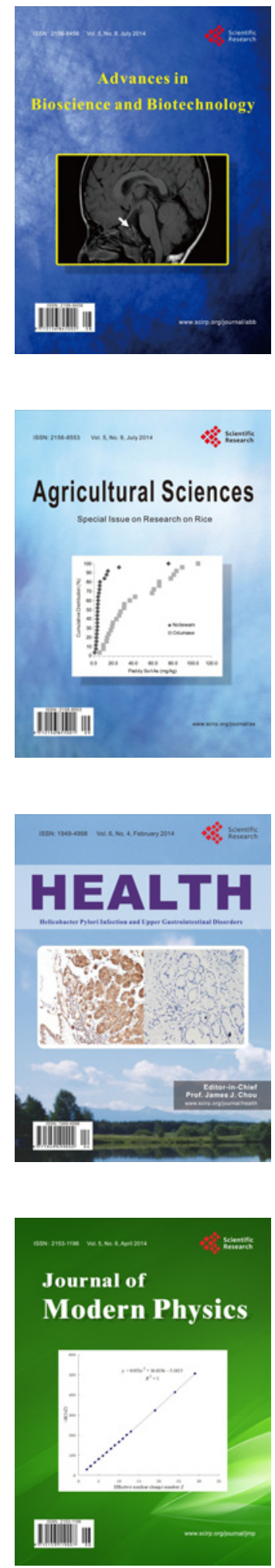
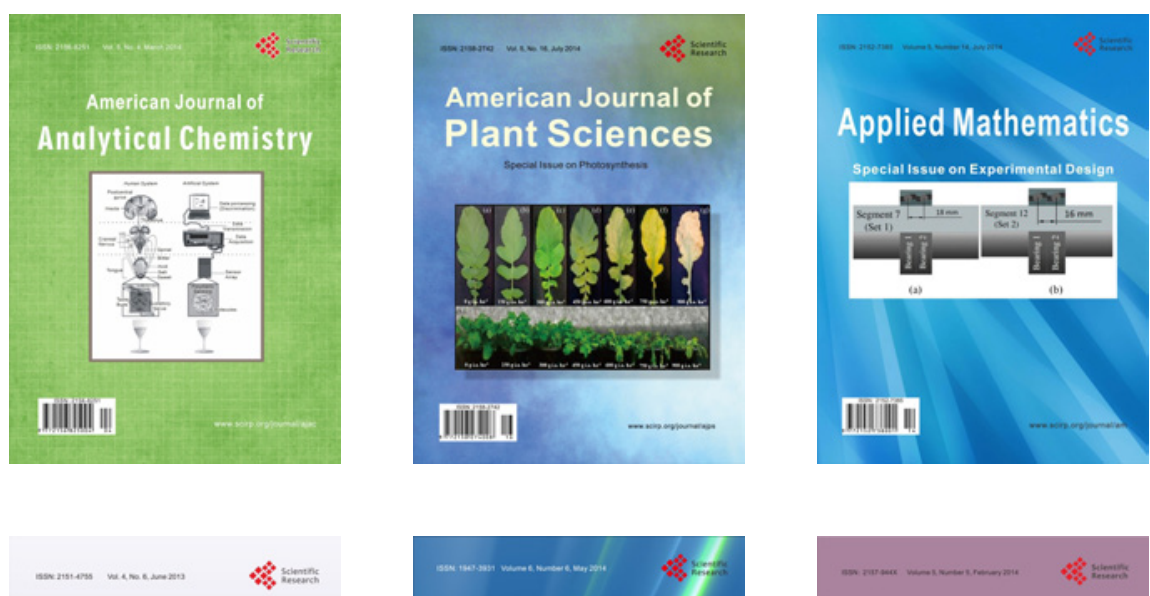

Creative Education
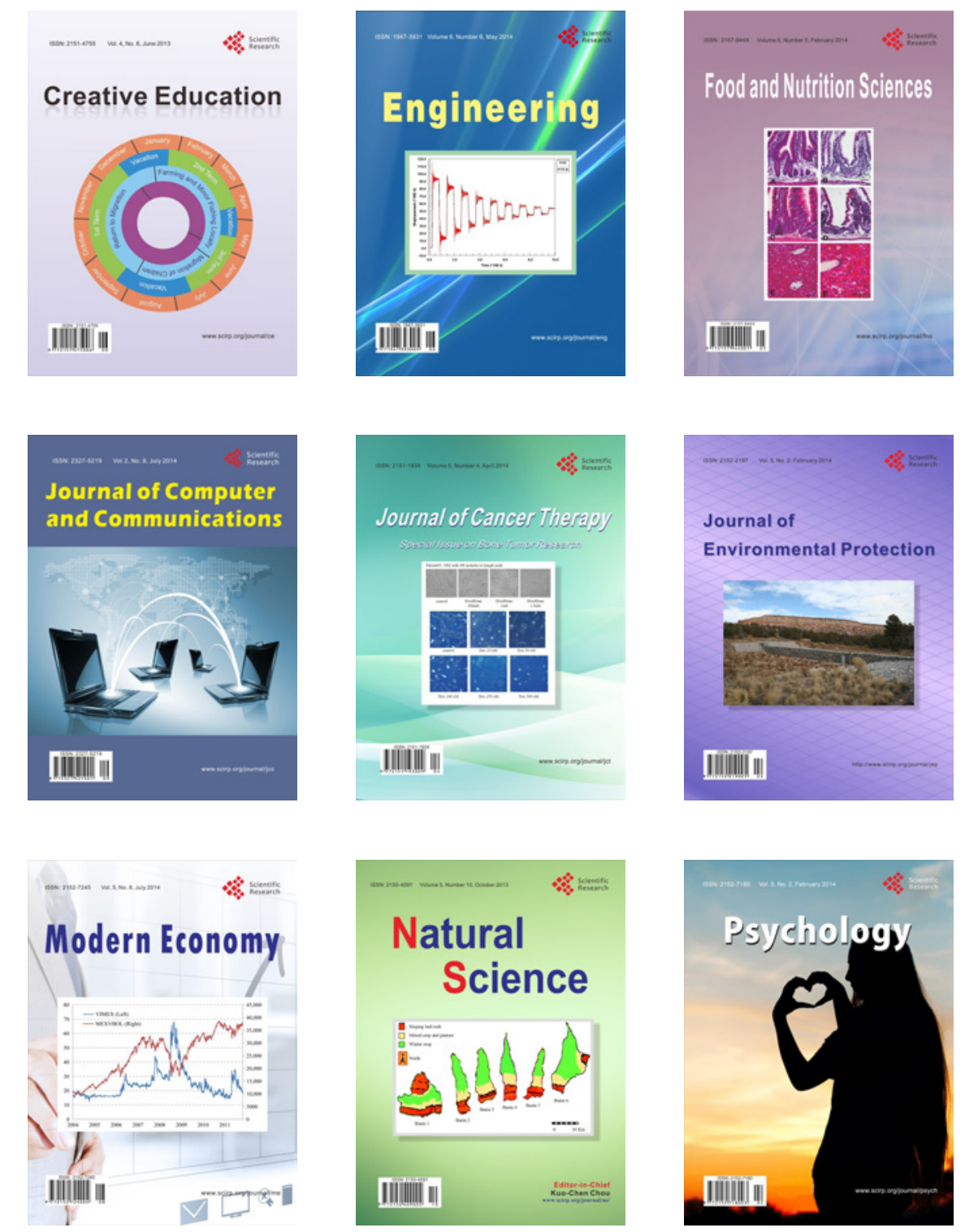